Carlsberg ridges. But, because of the fact that the divergonce of the velocity vector is zero, the components of flow along a ridge line cannot be zero all along the ridge. This is clear from Fig. 2, which shows that along the ridge in the southern hemisphere there is a southward component of flow parellel to the ridge and in the northern hemisphere a northward component. Only on the equator at intervals of $36^{\circ}$ of longitude does the horizontal flow completely vanish. These are above the main rising and falling columns of fluid.

It is thus necessary to determine from the ocean bottom topography where these points are before examining if they have any relation to the negative and positive gravity anomalies. The ocean rise is therefore a line from which flow diverges but having, in general, a component of flow along it. The positions of the rising columns are therefore to be located at the intersection of two oceanic rises. For at this point the foregoing condition for an ocean rise, that is, that the velocity perpendicular to it is zero, results in zero horizontal velocity. Fig. 1 shows the distribution of the ocean rises after Menard ${ }^{9}$. There are five clear cases where the ridges bifurcate or sharply change direction: (1) the intersection of the Pacific Antarctic rise with the rise running northwards into New Zealand; (2) the branching of the mid-Indian Ocean rise; (3) the join of the north and south Atlantic rises, associated with the east-west fractures near the equator; (4) the join of the East Pacific rise with the Pacific Antarctic rise; and (5) the northern extremity of the East Pacific rise in the Gulf of California.

Izsak $^{10}$ has recently published a map showing the $10-\mathrm{m}$ contours of the satellite geoid heights. These are ovals surrounding four points of maximum and five of minimum gravity. Fig. 1 shows the nine positions of these maxima and minima, their magnitudes and the contours surrounding them. It will be seen that a good correlation exists between the five points of minimum gravity and the five points of uprising currents determined from the topography. As this satellite gravity map is based on only those harmonic terms up to and including tho fourth degree and as the fifth is of equal importance with the third and fourth in the spherical harmonic expansion of the Farth's topography, the correlation is as good as it is reasonable to expect. Doubtless the inclusion of higher harmonic terms will move the points of maximum and minimum gravity to some extent.
On this view we would naturally associate the positive anomalies with the descending currents and therefore with zones of compression. The two zones of positive anomaly in south Europe and the Andes agree with this expectation very well. The elongated positive anomaly between the mid-Pacific and the East Indies ${ }^{12}$ covers a region of strong compression discovered by Vening Meinesz and the Tonga trench. The positive anomaly south of South Africa is of considerable interest, for little is known of the topography of the ocean floor in this region and points the need for investigation there.

It will at once be objected that the Tertiary mountain chains other than the Alps and Andes are not associated with positive anomalies. However, we must recall that on the theory of continental drift some continents have moved considorable distances in the past million years. Palæomagnetic evidence suggests that both India and Australia have moved considerable distances northward in this time. Both are now north of negative gravity anomalies and will still be experiencing a further northward force which may explain the Himalayas. Similarly, North America lies between two regions of uprising currents which must be exerting compressive forces which may have a fundamental connexion with the Rocky Mountain orogenies.

I thank Dr. H. W. Menard and Dr. R. W. Girdler for many discussions on the significance of the ocean ridges and Dr. J. H. Parry and Mrs. B. Gray for help with Fig. 2. I was stimulated to think about the problem presented by the gravity data discussion during a U.S. National Science Foundation conference on artificial satellites at the Virginia Polytechnic Institute, Blacksburg, Virginia, and with Dr. R. Kershner and his colleagues at the Applied Physics Laboratory, Silver Springs, Maryland.

1 Jeffreys, H., The Earth, fourth ed. (Camb. Univ. Press, 1959).

${ }^{3}$ Kaula, W. M., J. Geophys. Res., 68, 473 (1963).

Munk, W. H., and MacDonald, G. J. F., J. Geophys. Res., 65, 2169 (1960).

4 Cook, A. H., Nature, 198, 1186 (1963).

5 O'Keefe, J. A., Proc. Nat. Sci. Found. Conf. Artificial Satellites.

- Runcorn, S. K., Nature, 195, 1150 (1962).

'Runcorn, S. K., Nature, 193, 311 (1962).

- Runcorn, S. K., Nature, 195, 1248 (1962).

- Menard, H. W., Bull. C.S.A., 69, 1179 (1958).

${ }^{10}$ Izsak, I. G., Nature, 199, 137 (1963).

${ }^{11}$ Girdler, R. W., Nature, 198, 1037 (1963).

12 Vening Meinesz, F. A., Gravity Expeditions at Sea, 2 (Waltman, Delft, 1934).

\title{
OBITUARY
}

\section{Dr. W. J. Dowson}

Walter Joun Dowson, who was widely known for his research and teaching in plant pathology. died recently in Cambridge at the age of seventy-six. His career had been unusually full and varied. Originally a Scholar of Christ's College, Cambridge, he obtained first-class honours in the Natural Sciences Tripos, and followod this by two years' research in Germany. Then in 1913 he went as Government mycologist to Kenya, where he is remembered for his work on control of the coffee leaf rust fungus, Hemileia vastatrix. In 1920 he retumed to Great Britain as mycologist to the Royal Horticultural Society at Wisley, where he published work on variety of diseases caused by fungi. In 1928 he went abroad again, this time as Government plant pathologist in Tasmania, where his human qualities and professional ability combined to make him a great success with the growers.

The year 1932 marked a significant divide in Dowson's professional life; for the twenty years remaining until his official retirement, he was to be both a university teacher and $a_{0}$ more specialized research worker in a field that he was to make peculiarly his own. As a student at the Cambridge Botany School, he had early attracted the attention of Prof. F. T. Brooks. When, around 1932, a generous benefaction from the Rockefeller Foundation enabled a University Sub-Department of Mycology to be established within the Botany School, Brooks secured the appointment of Dowson as a University lecturer and as his colleague in the new Sub-Department. From that time until Brooks's retirement from the chair of botany in 1948 , the two of them were responsible for all the teaching and research in mycology, bacteriology and plant pathology carried out in the Botany School, and both will long be remembered by their former research students, now all over the world.

After ernsultation with Brooks on his return to Cambridge, Dowson decided to take up the investigation of plant diseases caused by bacteria - at that time a decidedly neglected branch of plant pathology. This was a farsighted decision; for the next twenty years and more, Dowson and his research students added greatly to our knowledge of these diseases. He was not content to confine himself to bacterial diserses occurring in Britain but extended his investigations to tropical plant patho- 


\section{No. 4907 November 16,1963}

gens, and carried on a voluminous correspondence with plant pathologists all over the world. Third-year students at the Cambridge Botany School benefited by a facility not available elsewhere in Britain - a comprehensive course of lectures and practical work devoted to bacterial pathogens of crop plants. Dowson's book, Manual of Bacterial Plant Diseases, first published in 1949, was the direct outcome of this course; as the most concise and readable text on this group of pathogens, it enjoyed a wide success. In 1957 a second edition was published, this time by the Cambridge University Press, under the title Plant Diseases due to Bacteria.

When Brooks retired from the chair of botany in 1948 , Dowson became the second director of the Sub-Depart. ment of Mycology, and continued as such until his own retirement in 1952. He did not retire from research, however, but continued active in laboratory work and in publication almost to the time of his death eleven years later. He will be remembered not only for an impressive contribution to his own subject, but also as a man who was inspired by lasting enthusiasm for his work purely for its own sake. His scientific merit was recognized by the University of London through its award of the D.Sc. degree; later, he also obtained the Sc.D. of Cambridge. He did not, perhaps, receive his full share of the material benefits and public recognition to which his scientific achievoments had undoubtedly entitled him. For this, there could have been two reasons. First, Dowson only began his best work after reaching the age of forty-five, and his international reputation came considerably later. Secondly, he was an extremely modest and even somewhat diffident man; people who did not know him or his work well were somewhat surprised to be told that his system of classification for plant pathogenic bacteria had gained such ready acceptance. What Dowson perhaps lost in his reluctance to thrust himself forward, he undoubtedly gained in human relationships. A most kindly man, with an ever-ready and generous interest in the affairs of other people, he never lost the common touch which had made him as popular with the applegrowers of Tasmania as with a generation of students at Cambridge.
S. D. GarRetT

\section{NEWS and VIEWS}

\section{The 1963 Nobel Prize for Physics and Chemistry}

ONe-HALF of the 1963 Nobel Prize for Physics has beon awarded jointly to Prof. Maria Goeppert-Mayer, professor of physics in the University of California, and Prof. J. Hans D. Jensen, professor of theoretical physics in the University of Heidelborg; the other half has been awarded to Prof. Eugen P. Wigner, professor of mathematical physics in Princeton University. The Chemistry Prize has been awarded jointly to Prof. Karl Ziegler, of the Institute for Carbon Research, Müllheim-Ruhr, and Prof. Giulio Natta, of the Institute of Technology, Milan.

\section{The Royal Society of London:}

Medal Awards

THe following awards of medals have been made by the President and the Council of the Royal Society: The Copley Medal, to Sir Paul Fildes, formerly director of chemical bacteriology at the Medical Research Council, for his pioneer contributions to bacteriology; The Davy Medal, to Dr. E. J. Bowen, Aldrichian praelector in chemistry at the University of Oxford, for his distinguished work on the elucidation of photochemical reactions, and for his study of fluorescence and phosphorescence in relation to the molecular processes concerned; The Hughes Medal, to Prof. F. C. Williams, professor of electrical engineering in the University of Manchester, for his distinguished work on early computers; The Leverhulme Medal (which was founded in 1960 by the Trustees of the Leverhulme Trust Fund to mark the occasion of the tercentenary of the Royal Society), to Dr. A. J. P. Martin, director of the Abbotsbury Laboratories, Ltd., for his distinguished and fundamental discoveries in chromatography and its application.

\section{Rutherford Memorial}

UNDER the terms of the scheme to commemorate the late Lord Rutherford of Nelson, the following appointments have been made: Sir George Thomson, formerly Master of Corpus Christi College, Cambridge, as Rutherford Memorial Lecturer, to lecture in August 1964 in New Zealand. Mr. H. S. Tan, formerly of Imperial College of Science and Technology and later at the Post Office Research Station, Dollis Hill, to hold a Rutherford Scholarship for three years from September 1963, to carry out research in the department of physics, McGill University, in solid-state physics.
Research Professorship

THE title of a Royal Society Research Professor has been given to Dame Honor Fell, Messel Research Fellow from 1931 until 1943 and Foulerton Research Follow since 1943. Dame Honor Fell, who is director of the Strangeways Research Laboratory, Cambridge, is well known for her work in the field of cell biology.

Visiting Professorship

DR. A. M. Lwoff, of the Institut Pasteur, Paris, has been appointed to be the Royal Society Visiting Professor for the academic yoar 1964-65. He is expected to take up appointment in April 1965 and to work in the division of virus ressarch at the National Institute for Medical Research, Mill Hill, London, N.W.7. Dr. Lwoff, who is a Foreign Member of the Royal Society, is distinguished for his work on the morphology and nutritional requirements of Protozoa, and for his researches on lysogenic bacteria and bacteriophage. Recently he has become interested in the growth of animal viruses and in normal defences against virus replication.

Guests

Academician E. N. Pavlovskir of the Academy of Sciences of the U.S.S.R. and his daughter Dr. Irena Bykhovskaya. Pavlovskaya arrived in London on October 31 for a stay of three and a half weeks as the guests of the Royal Society, collaborating with the British Council. The visits have been arranged under the agreement between the Royal Society and the Academy, which provides for the annual exchange visits of five senior scientists. Pavlovskii became an Academician in 1939, and in 1944 he became an Academician of the Academy of Medical Sciences of the U.S.S.R. He is director of the Institute of Zoology and Parasitology of the Academy, lieutenant-general of medical services, president of the Geographical Society of the U.S.S.R. and an Honorary Fellow of the Royal Society of Tropical Medicine and Hygiene. While in Britain, Academician Pavlovskii and his daughter will visit universities and other scientific institutions in London, Edinburgh, Liverpool and Cambridge. They will both deliver series of lectures. 